\title{
Focusing on Patient Needs and Preferences May Improve Genetic Counseling for Colorectal Cancer
}

\author{
Simone Salemink • Nicky Dekker • Carolien M. Kets • \\ Erica van der Looij • Wendy A. G. van Zelst-Stams • \\ Nicoline Hoogerbrugge
}

Received: 30 September 2011 / Accepted: 14 June 2012 /Published online: 23 August 2012

(C) The Author(s) 2012. This article is published with open access at Springerlink.com

\begin{abstract}
During cancer genetic counseling, different items which counselors consider important are discussed. However, relatively little empirical evidence exists regarding the needs and preferences of counselees. In this study needs and preferences were assessed from counselees with a personal and/or family history of colorectal cancer (CRC), who were referred for genetic counseling regarding CRC. They received a slightly modified version of the QUOTEGENE $^{\mathrm{ca}}$ questionnaire prior to their first visit to the Hereditary Cancer Clinic. Response rate was $60 \%$ (48/80 participants). Counselees rated the importance of 45 items assessing their needs and preferences regarding the content and process of genetic counseling. Participants rated the items regarding discussion of information about their familial CRC risk (100\%) and preventive options $(98 \%)$ as important or very important. Fewer participants rated items concerning general information on genetics as important. Sensitive communication during counseling was considered very important by a large percentage of counselees. Generally, no major differences were seen between participants in relation to individual characteristics. Our data suggest that
\end{abstract}

\footnotetext{
S. Salemink $\cdot$ N. Dekker $\cdot$ C. M. Kets $\cdot$ E. van der Looij $\cdot$

W. A. G. van Zelst-Stams $\cdot$ N. Hoogerbrugge $(\bowtie)$

Department of Human Genetics 836,

Radboud University Nijmegen Medical Centre,

P.O. Box 9101, 6500 HB, Nijmegen, The Netherlands

e-mail: N.Hoogerbrugge@gen.umcn.nl

N. Dekker

Scientific Institute for Quality of Healthcare,

Radboud University Nijmegen Medical Centre,

Nijmegen, The Netherlands

N. Hoogerbrugge

Department of Medical Oncology,

Radboud University Nijmegen Medical Centre,

Nijmegen, The Netherlands

focusing on familial CRC risk and surveillance options, in combination with sensitive communication may lead to better satisfaction with genetic counseling.

Keywords Genetic counseling · Patient preferences · Colorectal neoplasms

\section{Introduction}

The lifetime risk of developing colorectal cancer (CRC) in Western society is approximately 5-6\% (Jemal et al. 2009; The Netherlands Cancer Registry). The majority of these patients have sporadic CRC, while familial and hereditary cancers account for approximately $15 \%$ to $20 \%$ of all CRCs (de Jong and Vasen 2006; Grover et al. 2004; Lynch and de la Chapelle 2003). In these families, healthy relatives of CRC patients have an increased risk of developing CRC themselves, which may be prevented by surveillance colonoscopies (Dove-Edwin et al. 2005; Jarvinen et al. 2000).

Familial CRC risk is generally divided into three groups, based on cumulative lifetime risks of developing CRC (Dutch Society for Clinical Genetics 2008):

- Average-familial CRC risk below $10 \%$

- Moderate-familial CRC risk of 10-15\%

- High-familial CRC risk above $15 \%$

For patients with a high familial CRC risk, referral for genetic counseling is recommended. During genetic counseling, patients and their relatives receive information on the consequences and nature of hereditary CRC, the most common being Lynch syndrome. In a subset of families, genetic analysis for Lynch syndrome is performed by microsatellite instability (MSI) and/or DNA-testing. Based on these test results and the interpreted family history, a tailored surveillance plan is proposed by the clinical geneticist or genetic 
counselor. Regular surveillance by colonoscopy is crucial for individuals with an increased familial CRC risk, as it can reduce CRC-related morbidity and mortality up to $80 \%$ (Dove-Edwin et al. 2005; Jarvinen et al. 2000).

Currently, most at-risk individuals for CRC have not had a surveillance colonoscopy (Longacre et al. 2006). Amongst other reasons, one underlying cause seems to be the inadequate recognition of individuals at risk for CRC. To improve this aspect of healthcare, a new Dutch guideline on familial and hereditary CRC was introduced in 2008, in which clinicians have new tasks in calculating, interpreting, and communicating familial CRC risk (Dutch Society for Clinical Genetics 2008). These tasks should lead to better recognition of individuals at an increased familial CRC risk, enabling them to undergo surveillance colonoscopies.

Family history, the basis of clinical indication, does not predict by itself whether an individual undergoes CRC surveillance or not (Griffith et al. 2008). Therefore, there must be other barriers for at-risk individuals to undergo surveillance. Some of these barriers might even be related to socio-demographic factors, such as age (Bleiker et al. 2005) or education level (Halbert et al. 2004). However, several studies showed that recommendation for CRC screening by a healthcare provider is a significant predictor of timely screening for individuals at increased risk for CRC (Griffith et al. 2008; Lewis et al. 2006). Interventions also seem to be most successful when recommendations are tailored to individuals or communities (Powe et al. 2010). From this perspective, tailoring genetic counseling to the needs and preferences of the counselee may lead to better understanding of the importance of CRC screening and thus increase surveillance uptake.

The traditional model for cancer genetic counseling focuses on the systematic discussion of cancer genetics, medical facts, risks of developing cancer, psychosocial consequences, and surveillance policy. This model is based on general key goals of genetic counseling regarding hereditary cancer as previously established by the counselors: (a) identifying individual needs and concerns of the counselee, (b) providing information on genes and chromosomes, (c) giving an individual risk assessment in the context of supportive interaction, and (d) discussing the pros and cons of genetic testing and drawing up a surveillance plan (Lobb et al. 2001). During counseling, careful attention must also be given to the patient's autonomy and ability to make well-informed decisions regarding testing and adoption of preventive strategies (Robson et al. 2010; Lobb et al. 2002).

Counselors' main goals of genetic counseling for hereditary CRC are well known; however, to our knowledge, the needs and preferences of counselees have scarcely been assessed. Previous studies investigated women's preferences for the genetic counseling aspects of providing cancer, gene, and risk information (information); giving advice about cancer surveillance (surveillance); preparing for genetic testing (preparation); and assistance with decision-making (direction). The researchers found that women who were offered $B R C A 1 / 2$ testing had the highest preference for getting information and lowest preference for direction (Apicella et al. 2005; Peacock et al. 2006). Counselees may also need information about the genetic counseling procedure prior to a first counseling visit (Pieterse et al. 2005b).

Yet, in order to provide optimal tailoring of genetic counseling for hereditary CRC, further investigation of specific needs and preferences of the counselee and their relation to socio-demographic factors is required. Knowing what patients need and prefer enables the counselor to tailor information on a surveillance plan as much as possible. Such a personalized recommendation for CRC screening by a healthcare provider may increase the probability that those individuals at risk for CRC will undergo timely surveillance.

This exploratory pilot study was performed to answer the following research questions: 1) During genetic counseling, which counseling items and communication strategies are important to counselees suspected of hereditary CRC? and 2) Are counselees' preferences related to their individual characteristics such as medical history, genetic counseling history, gender, and age?

\section{Methods}

\section{Participants}

Counselees referred to the Hereditary Cancer Clinic of the Radboud University Nijmegen Medical Centre, the Netherlands, between May 2010 and July 2010 for genetic counseling on hereditary colorectal cancer (CRC) were eligible for this study. Inclusion criteria were (a) referral for genetic counseling for familial CRC or Lynch syndrome, and (b) age 18 years and above. Counselors included both clinical geneticists and genetic counselors. Due to ethical reasons, no data were collected from non-participants.

\section{Procedures}

To evaluate counselees' requirements concerning genetic counseling in case of hereditary cancer, an instrument called QUOTE-gene ${ }^{\mathrm{ca}}$ was developed by Pieterse et al. (Pieterse et al. 2005a). In the current study, counselees received a standard invitation to the Hereditary Cancer Clinic, as well as a pre-visit anonymous questionnaire based on QUOTEgene $^{\text {ca }}$. Counselees were asked to return the questionnaire within 1 week. Clinical records were consulted to determine the medical status of the participant (affected or unaffected with $\mathrm{CRC}$ ) and whether the counselee was the first in the family seeking genetic advice (index patient) or sought 
presymptomatic testing (in case of a known mutation in the family). Mutation carriers were offered surveillance by regular colonoscopies. Non-carriers (true negatives, being patients in whom a known family mutation is not found) were told that undergoing surveillance was unnecessary. If there was no known family mutation and no mutation was found in the patient, either no surveillance plan or a less intensive surveillance plan was drawn up according to national guidelines for familial CRC, based on family history.

\section{Questionnaire}

The first part of the pre-visit questionnaire assessed gender, age, education level and nationality. The main part of the questionnaire was based on the QUOTE-gene ${ }^{\text {ca }}$ questionnaire (Pieterse et al. 2005a), which in turn is derived from the QUOTE scale ('Quality of Care Through the Patients' Eyes') (Sixma et al. 2000). The QUOTE-gene ${ }^{\text {ca }}$ questionnaire intends to measure needs and preferences in genetic counseling for hereditary cancer. This questionnaire has been shown to capture relevant issues of concern with a high internal consistency, and is associated with previously validated measures of coping style and distress (Pieterse et al. 2005a). Some items were rephrased, without changing the content of each item. For example, the item "my risk or the risk for my family" was split into two separate items: "my own risk" and "the risk for my family." Also, an item about "the option of additional support by a social worker" was added. As these are minor changes, we expect the psychometric properties of our questionnaire to be comparable to the original QUOTE-gene ${ }^{\mathrm{ca}}$ questionnaire.

The questionnaire contained a list of cancer-specific items and a list of generic items. Cancer-specific items included "own risk of developing cancer," "determination and meaning of being a carrier of a cancer gene," "emotional aspects for counselee and family," and "heredity of cancer in general." Generic items included "procedural aspects of counseling," "sensitive communication," "emotional support," and "assessment of susceptibility to the disease." Counselees rated the importance of each item using a fourpoint, Likert-type scale $(1=$ not important, 2 = fairly important, 3 = important, $4=$ extremely important). For data analysis, ratings 1 and 2 were merged to "(not or fairly) important" and ratings 3 and 4 to "(very) important."

\section{Data Analysis}

The interrelations between patients' needs and preferences and their individual characteristics were compared using cross tabs and the Fisher's Exact test. Individual characteristics used in the statistical analyses were: gender (men versus women), age ( $<35$ years versus aged $35-50$ years, versus $>50$ years), medical status (affected with CRC versus unaffected with CRC), education (low versus middle versus high) and medical background (medical background versus no medical background). Education levels were subdivided into "low" (primary school), "middle" (junior and senior secondary vocational education), and "high" (higher vocational education and university education). All computations were done with the SPSS statistical package (release 16.0). Two-sided $p$-values below 0.05 were considered to be statistically significant.

\section{Results}

\section{Participants}

Forty-eight of 80 counselees $(60 \%)$ participated in this study. Table 1 shows the baseline characteristics of these 48 participants. There were 22 men $(46 \%)$ and 26 women (54\%). Their mean age upon completion of the questionnaire was 51.6 years $(\mathrm{SD}=11.3$; Range: $19-72)$.

Table 1 Participant baseline characteristics $(n=48)$

\begin{tabular}{|c|c|c|}
\hline & $n^{\mathrm{a}}$ & $\%$ \\
\hline \multicolumn{3}{|l|}{ Age (years) } \\
\hline Mean (s.d.) & $51.6(11.3)$ & \\
\hline Range & $19-72$ & \\
\hline \multicolumn{3}{|l|}{ Gender } \\
\hline Men & 22 & 46 \\
\hline Women & 26 & 54 \\
\hline \multicolumn{3}{|l|}{ Kind of referral } \\
\hline First in family seeking advice (index) & 40 & 83 \\
\hline Presymptomatic & 7 & 15 \\
\hline \multicolumn{3}{|l|}{ Personal medical history } \\
\hline Participant affected with CRC & 15 & 31 \\
\hline Participant unaffected with CRC & 33 & 69 \\
\hline \multicolumn{3}{|l|}{ Education $^{\mathrm{b}}$} \\
\hline Low & 15 & 31 \\
\hline Middle & 20 & 42 \\
\hline High & 12 & 25 \\
\hline \multicolumn{3}{|l|}{ Social status } \\
\hline Living together (cohabitation, married) & 39 & 81 \\
\hline Living alone (single, widow, divorced) & 9 & 19 \\
\hline \multicolumn{3}{|l|}{ Medical background } \\
\hline No & 40 & 83 \\
\hline Yes & 7 & 15 \\
\hline \multicolumn{3}{|l|}{ Nationality } \\
\hline Dutch & 46 & 96 \\
\hline Other & 2 & 4 \\
\hline
\end{tabular}

${ }^{\mathrm{a}}$ Sample sizes vary due to missing data; ${ }^{\mathrm{b}}$ Low $=$ primary school; Middle $=$ junior and senior secondary vocational education; High $=$ higher vocational education and university education 


\section{Needs and Preferences Prior to the First Visit}

As shown in Table 2, counselor provision of information about the counselee's own risk of developing (a second) $\mathrm{CRC}$, as well as this risk for relatives, was rated as important by every participant $(100 \%)$. Almost every participant wanted to know what to do if they had an increased risk of developing CRC (98\%). Counselor explanation of emotional consequences for themselves and for their family were rated as (very) important by $70 \%$ and $81 \%$ of participants, respectively. Fewer participants considered the items about heredity of cancer in general as (very) important, e.g. the prevalence of cancer in the Netherlands (35\%).

With regard to generic items of genetic counseling, all participants considered it (very) important that the counselor takes them seriously, listens carefully, gives enough time and attention, involves them in decisions that are made, and

Table 2 Frequencies of counselees' ratings of cancer-specific needs and preferences as important or very important $(n=48)^{\mathrm{a}}$

\begin{tabular}{|c|c|c|}
\hline \multirow{2}{*}{$\begin{array}{l}\text { During counseling, the counselor should } \\
\text { explain... }\end{array}$} & \multicolumn{2}{|c|}{ (Very) importan } \\
\hline & $n$ & $\%$ \\
\hline How risks for myself and my family are computed & 46 & 96 \\
\hline \multicolumn{3}{|l|}{ Own risk of developing cancer } \\
\hline My risk of developing cancer (again) & 48 & 100 \\
\hline What to do if I have an increased risk of cancer & 46 & 98 \\
\hline $\begin{array}{l}\text { What to do if I do not have an increased risk } \\
\text { of cancer }\end{array}$ & 36 & 77 \\
\hline \multicolumn{3}{|c|}{ Determination and meaning of being a carrier of a cancer gene } \\
\hline Whether the cancer in my family is hereditary & 45 & 94 \\
\hline $\begin{array}{l}\text { Why I am/am not considered for further } \\
\text { examination }\end{array}$ & 44 & 94 \\
\hline What it means to be a carrier of a certain gene & 43 & 90 \\
\hline Possibilities of DNA-testing & 43 & 90 \\
\hline What it means to be a carrier of a cancer gene & 43 & 90 \\
\hline Limitations of DNA-testing & 41 & 85 \\
\hline The procedure of DNA-testing & 39 & 81 \\
\hline \multicolumn{3}{|l|}{ Emotional aspects for counselee and family } \\
\hline $\begin{array}{l}\text { My family members' risk of developing cancer } \\
\text { (again) }\end{array}$ & 47 & 100 \\
\hline What it means not to be a carrier of a cancer gene & 40 & 83 \\
\hline $\begin{array}{l}\text { Emotional consequences for my family as a result } \\
\text { of genetic counseling }\end{array}$ & 38 & 81 \\
\hline The procedure of studying the family history & 35 & 74 \\
\hline $\begin{array}{l}\text { Emotional consequences for myself as a result of } \\
\text { genetic counseling }\end{array}$ & 33 & 70 \\
\hline \multicolumn{3}{|l|}{ Heredity of cancer in general } \\
\hline How cancer is inherited in a family & 41 & 85 \\
\hline How often cancer is hereditary & 34 & 71 \\
\hline $\begin{array}{l}\text { Background information (chromosomes, DNA, } \\
\text { genes) }\end{array}$ & 34 & 71 \\
\hline The prevalence of cancer in the Netherlands & 17 & 35 \\
\hline
\end{tabular}

${ }^{a}$ Sample sizes vary due to missing data provides clear and understandable explanations (100\%). These items represent sensitive communication during genetic counseling; every item in this category was rated as (very) important by all or almost every participant. Fewer participants considered discussion by the counselor of the option of additional support by a social worker (44\%), communication with family members $(60 \%)$, and talking about the emotional aspects of the diagnostic procedure $(65 \%)$ as (very) important. These items represent emotional support during genetic counseling (see Table 3).

Table 3 Frequencies of counselees' ratings of generic needs and preferences as important or very important $(n=48)^{\mathrm{a}}$

\begin{tabular}{|c|c|c|}
\hline \multirow[t]{2}{*}{ During counseling, the counselor should... } & \multicolumn{2}{|c|}{ (Very) important } \\
\hline & $n$ & $\%$ \\
\hline $\begin{array}{l}\text { Provide me with clear and understandable } \\
\text { explanations }\end{array}$ & 48 & 100 \\
\hline \multicolumn{3}{|l|}{ Sensitive communication } \\
\hline Take me seriously & 48 & 100 \\
\hline Listen carefully & 48 & 100 \\
\hline Give me enough time and attention & 48 & 100 \\
\hline Involve me in the decisions that are made & 48 & 100 \\
\hline Be skilled & 47 & 98 \\
\hline Give advice & 47 & 98 \\
\hline Give me the opportunity to ask questions & 47 & 98 \\
\hline Be open to my wishes, values and my opinions & 43 & 90 \\
\hline \multicolumn{3}{|l|}{ Procedural aspects of counseling } \\
\hline Give medical information & 46 & 96 \\
\hline Explain the procedure of genetic counseling & 46 & 96 \\
\hline Be punctual with appointments & 45 & 94 \\
\hline Inform me sufficiently about what to expect & 44 & 92 \\
\hline $\begin{array}{l}\text { Cooperate well with my other doctors, e.g. GP or } \\
\text { specialist }\end{array}$ & 44 & 92 \\
\hline Give the opportunity to ask questions at any time & 44 & 92 \\
\hline Explain the roles of the providers & 42 & 88 \\
\hline $\begin{array}{l}\text { Tell me how much time the diagnostic procedure } \\
\text { takes }\end{array}$ & 32 & 67 \\
\hline \multicolumn{3}{|l|}{ Assessment of susceptibility to disease } \\
\hline Tell me what the risk for my family is & 46 & 96 \\
\hline Tell me what my risk is & 44 & 94 \\
\hline Carry out a DNA-test on me or a family member & 39 & 81 \\
\hline Analyze the family history & 38 & 81 \\
\hline \multicolumn{3}{|l|}{ Emotional support } \\
\hline Provide me (also) with written information & 43 & 90 \\
\hline Reassure me & 36 & 77 \\
\hline Show understanding and sympathy & 36 & 75 \\
\hline $\begin{array}{l}\text { Talk about the emotional aspects of the diagnostic } \\
\text { procedure }\end{array}$ & 31 & 65 \\
\hline Discuss communication with family members & 28 & 60 \\
\hline $\begin{array}{l}\text { Discuss the option of additional support by a social } \\
\text { worker }\end{array}$ & 21 & 44 \\
\hline
\end{tabular}

${ }^{\text {a }}$ Sample sizes vary due to missing data 
Items Involving Cancer-Specific Topics

Unaffected participants were more likely to consider receiving information about the procedure of studying the family history (very) important compared to participants affected with cancer, $p=0.025$. In other words, a greater percentage of healthy participants wanted to know how a genetic risk assessment is made compared to affected patients ( $85 \%$ vs. $50 \%$, respectively). As reported previously, receiving an explanation about their own risk of developing cancer or developing cancer again was rated as (very) important by all participants. Thus, no major differences due to participants' background variables were seen for this item. No other significant relationships were obtained for participant characteristics and their ratings of the cancer-specific questionnaire items.

Differences on Generic Items Due to Participants' Individual Characteristics

Sensitive communication was (very) important for almost all participants and was not significantly related to their individual characteristics. However, women more often than men rated the item 'the counselor is open to their wishes, values and opinions' as (very) important, $p=0.015(100 \%$ vs. $77 \%$, respectively). No other significant differences on general items were seen as a function of participants' individual characteristics.

\section{Discussion}

\section{Major Findings}

The results of this study show that the most prevalent information topics perceived as important by counselees prior to their first genetic counseling session are their familial colorectal cancer risk and surveillance options. Additionally, sensitive communication during genetic counseling is considered of extreme importance by counselees. Fewer counselees considered emotional aspects and general information on genetics as important. Ratings of the importance of needs and preferences generally did not differ significantly between the different socio-demographic groups.

The Meaning and Importance of These Findings

Sensitive communication during counseling was considered very important as well by a large percentage of counselees. Especially, counselees consider it very important that the counselor takes him or her seriously, listens carefully, gives enough time and attention, and involves him or her in the decisions that are made. Evidently, the interaction between counselor and counselee is viewed as fundamental for successful counseling. This was also seen in a study by Veach et al. (2007), who published the results of a consensus meeting among genetic counselors and other healthcare professionals, in which they describe a reciprocal-engagement model of genetic counseling practice including goals and strategies that can be used during the genetic counseling process.

Our results can be used to adapt future genetic counseling on hereditary CRC to the needs and preferences of the counselee. By better adapting the genetic counseling to the needs and preferences of the counselee, consultation time can be saved and used to explain important and complex issues instead, such as familial CRC risk and surveillance options for those who are at risk for CRC. The focus of genetic counseling must be on topics considered important and less on topics not considered essential by both counselor and counselee. By adapting genetic counseling to counselees' preferences, counseling may become more effective and more attention can be given to surveillance options for those who warrant surveillance.

Although generally no significant differences in needs and preferences were found in relation to counselees' socio-demographic characteristics, it is important to keep in mind that every counselee has specific needs and preferences based on other factors. Besides, this study showed that sensitive communication was considered very important by every counselee. Counselors should take into account what might explain observed trends in different needs and preferences. For example, presymptomatic counselees may consider emotional aspects during genetic counseling more important than patients who are the first members of a family seeking advice on hereditary CRC. These so-called index patients may not always foresee possible outcomes. In addition, in this study, healthy participants were more likely to consider it important to understand the process of genetic risk assessment compared to affected participants. It is possible that participants with CRC consider risk assessment less important because they were affected already with CRC. Also, the present findings suggest women consider it more important than men that the counselor is open to their wishes, values, and opinions. One explanation could be that men have more interest in facts and medical information, while women consider communication itself more important. In consideration of these interpersonal differences, counselors always need to verify a counselee's personal background and adapt their counseling to their individual situation.

\section{Relation of the Findings to Those of Similar Studies}

The results of our study are partly in line with findings from other research. Peacock et al. (2006) showed that women's preferences include information and surveillance advice. 
Our study distinguishes between medical information (see Table 3) and background information (see Table 2) and shows that especially medical information is considered (very) important by $96 \%$ of the counselees. The need for background information on chromosomes, DNA, and genes is considered (very) important by $71 \%$ of the counselees.

Our results also concur with previous findings by Pieterse et al. (Pieterse et al. 2005a). In their study, 200 new counselees, primarily counseled for breast and colon cancer, completed a QUOTE-gene ${ }^{\text {ca }}$ questionnaire prior to their first consultation. They found that the patients' preferences when interacting with the counselor were receiving information, risk and preventive strategies for oneself and/or family members and information about the procedure of genetic counseling. Less patients considered emotional support and discussing emotional aspects as very important beforehand. However, $91 \%$ of the counselees in that study were women. This leads to difficulties with extrapolation of these findings to genetic counseling for late-onset diseases that men and women seek more equally, such as CRC. Although the power of our study was limited, no major significant differences in needs and preferences between men and women were found. This indicates that this instrument can be meaningfully adapted to counselees for other types of late-onset hereditary cancers.

In another study by Pieterse et al., 130 counselees, referred mainly for breast or colon cancer, completed a questionnaire containing the QUOTE-gene ${ }^{\mathrm{ca}}$ before their first appointment at a genetic clinic (Pieterse et al. 2005b). They showed that counselees had a stronger psychosocial focus than counselors, as counselees initiated the discussion of emotional consequences of DNA testing more often than their counselor, compared to other topics assessed. However, our study shows that counselees seeking presymptomatic testing consider emotional aspects of genetic counseling more important than those who are the first in the family seeking genetic advice. Providing more information on the counseling content and procedure prior to their visit may prepare counselees for possible unforeseen consequences of genetic counseling. Furthermore, new counselees may be advised to prepare for the visit more thoroughly, allowing them to verbalize questions more frequently during consultation (Albada et al. 2011; Pieterse et al. 2005b).

\section{Study Limitations}

The results of our study are based on a limited number of counselees from one country. In addition, $40 \%$ of the eligible participants did not enroll in this study, possibly limiting generalizability of the results. Since no data were collected for the non-participants, the possibility of an enrollment bias cannot be excluded. However, a strength of our study is that the group of participating counselees was very diverse, for instance in age, being affected with cancer or not, education, and gender. Another limitation to consider is that, by asking preselected questions, participants get an idea of possible items being addressed during genetic counseling. The fact that these items are proposed in the questionnaire, implies that they are at least important to someone else. This may be the reason that some participants were inclined to score all topics as (very) important, which may cause a social desirability bias. Also, a four point scale without a mid-point appears to push more respondents towards the positive end of the scale (Worcester and Burns 1975). In addition, educational level may have influenced counselees' understanding of the questionnaire items. However, the percentage of low educated participants is normal compared to the general population and almost all questions were answered in which no differences were seen among counselees with different education levels, suggesting that this was not the case.

\section{Practice Implications and Research Recommendations}

The results of our study may contribute to optimal adaptation of genetic counseling for hereditary colorectal cancer to counselees' needs. Focusing on familial CRC risk and surveillance options may lead to better satisfaction with genetic counseling and improved adherence to surveillance policies. However, it remains important for all counselors to keep in mind that every counselee has their own specific needs and preferences. Since there is great variability among counselees, using a questionnaire such as the QUOTE-gene ${ }^{\mathrm{ca}}$ prior to the first genetic counseling session may help genetic counselors to determine which items to discuss with the counselee. However, it is necessary to explore the best content and format as well as assess the added value of this strategy. Additionally, larger studies are needed to determine whether indeed, very few differences in needs and preferences are present between counselees with different socio-demographics. It will also be necessary to explore whether patient satisfaction and surveillance uptake for colorectal cancer can indeed be improved in this manner.

Acknowledgements We would like to thank the participants in this study, Dr. P. Manders for her help with the statistical analyses, and Dr. A. Sie for her help with the grammar. This study was supported by a grant from ZonMw - the Netherlands Organization for Health Research and Development (no. 80-82315-98-09005) and was approved by the Committee on Research Involving Human Subjects of the region Arnhem-Nijmegen (ABR no. NL25311.091.08).

Open Access This article is distributed under the terms of the Creative Commons Attribution License (https://doi.org/ creativecommons.org/licenses/by-nc/2.0/), which permits any use, distribution, and reproduction in any medium, provided the original author(s) and the source are credited.

\section{References}

Albada, A., Ausems, M., Otten, R., Bensing, J., \& van Dulmen, S. (2011). Use and evaluation of an individually tailored website for counselees prior to breast cancer genetic counseling. Journal of Cancer Education, 26(4), 670-681. 
Apicella, C., Peacock, S., Andrews, L., Tucker, K., Bankier, A., Daly, M., et al. (2005). Determinants of preferences for genetic counselling in Jewish women. Familial Cancer, 5(2), 159-167.

Bleiker, E., Menko, F., Taal, B., Kluijt, I., Wever, L., Gerritsma, M., et al. (2005). Screening behavior of individuals at high risk for colorectal cancer. Gasteroenterology, 128(2), 280-287.

De Jong, A., \& Vasen, H. (2006). The frequency of a positive family history for colorectal cancer: a population-based study in the Netherlands. Netherlands Journal of Medicine, 64(10), 367-370.

Dove-Edwin, I., Sasieni, P., Adams, J., \& Thomas, H. (2005). Prevention of colorectal cancer by colonoscopic surveillance in individuals with a family history of colorectal cancer: 16 year, prospective, follow-up study. British Medical Journal, $331(7524), 1047$.

Dutch Society for Clinical Genetics. (2008). CBO Guideline Hereditary Colorectal Cancer. http://www.oncoline.nl

Griffith, K., McGuire, D., Royak, R., Plowden, K., \& Steinberger, E. (2008). Influence of family history and preventive health behaviors on colorectal cancer screening in African Americans. Cancer, 113(2), 276-285.

Grover, S., Stoffel, E., Bussone, L., Tschoegl, E., \& Syngal, S. (2004). Physician assessment of family cancer history and referral for genetic evaluation in colorectal cancer patients. Clinical Gastroenterology and Hepatology, 2(9), 813-819.

Halbert, C., Lynch, H., Lynch, J., Main, D., Kucharski, S., Rustgi, A., et al. (2004). Colon cancer screening practices following genetic testing for hereditary nonpolyposis colon cancer (HNPCC) mutations. Archives of Internal Medicine, 164(17), 1881-1887.

Jarvinen, H., Aarnio, M., Mustonen, H., Aktan-Collan, K., Aaltonen, L., Peltomaki, P., et al. (2000). Controlled 15-year trial on screening for colorectal cancer in families with hereditary nonpolyposis colorectal cancer. Gastroenterology, 118(5), 829-834.

Jemal, A., Siegel, R., Ward, E., Hao, Y., Xu, J., \& Thun, M. (2009). Cancer statistics, 2009. CA: A Cancer Journal for Clinicians, 59 (4), 225-249.

Lewis, C., Kistler, C., Amick, H., Watson, L., Bynum, D., Walter, L., et al. (2006). Older adults' attitudes about continuing cancer screening later in life: a pilot study interviewing residents of two continuing care communities. BMC Geriatrics, 3(6), 10.

Lobb, E., Butow, P., Meiser, B., Tucker, K., \& Barratt, A. (2001). How do geneticists and genetic counselors counsel women from high- risk breast cancer families? Journal of Genetic Counseling, 10(5), 393-405.

Lobb, E., Butow, P., Meiser, B., Barratt, A., Gaff, C., Young, M., et al. (2002). Tailoring communication in consultations with women from high risk breast cancer families. British Journal of Cancer, 87(5), 502-508.

Longacre, A., Cramer, L., \& Gross, C. (2006). Screening colonoscopy use among individuals at higher colorectal cancer risk. Journal of Clinical Gastroenterology, 40(6), 490-496.

Lynch, H., \& de la Chapelle, A. (2003). Hereditary colorectal cancer. New England Journal of Medicine, 348(10), 919-932.

Peacock, S., Apicella, C., Andrews, L., Tucker, K., Bankier, A., Daly, M., et al. (2006). A discrete choice experiment of preferences for genetic counselling among Jewish women seeking cancer genetics services. British Journal of Cancer, 95(10), 1448-1453.

Pieterse, A., van Dulmen, S., Ausems, M., Schoemaker, A., Beemer, F., \& Bensing, J. (2005a). QUOTE-gene(ca): development of a counselee-centered instrument to measure needs and preferences in genetic counseling for hereditary cancer. Psychooncology, 14 (5), 361-375.

Pieterse, A., van Dulmen, A., Ausems, M., Beemer, F., \& Bensing, J. (2005b). Communication in cancer genetic counselling: does it reflect counselees' previsit needs and preferences? British Journal of Cancer, 92(9), 1671-1678.

Powe, B., Faulkenberry, R., \& Harmond, L. (2010). A review of intervention studies that seek to increase colorectal cancer screening among African-Americans. American Journal of Health Promotion, 25(2), 92-99.

Robson, M., Storm, C., Weitzel, J., Wollins, D., \& Offit, K. (2010). American Society of Clinical Oncology policy statement update: genetic and genomic testing for cancer susceptibility. Journal of Clinical Oncology, 28(5), 893-901.

Sixma, H., van Campen, C., Kerssens, J., \& Peters, L. (2000). Quality of care from the perspective of elderly people: the QUOTEelderly instrument. Age and Ageing, 29(2), 173-178.

Veach, P., Bartels, D., \& Leroy, B. (2007). Coming full circle: a reciprocal-engagement model of genetic counseling practice. Journal of Genetic Counseling, 16(6), 713-728.

Worcester, R., \& Burns, T. (1975). A statistical examination of the relative precision of verbal scales. Journal of the Market Research Society, 17(3), 181-197. 